\title{
Exploring the relationship between workaholism and personality traits among public organization managers
}

\author{
Marjan Fayyazi $^{\mathrm{a}}$, Ghasem Eslami ${ }^{\mathrm{w}}$, Yoones Kermanshahian ${ }^{\mathrm{c}}$ and Negar Mazloomhoseini $^{\mathrm{d}}$
}

\author{
${ }^{a}$ Assistant Professor, Faculty of Management, University of Tehran \\ ${ }^{b}$ Master Student of management Department, Ferdowsi University of Mashhad, Iran \\ ${ }^{c}$ Master Student of Management Department, Mehralborz University, Tehran, Iran \\ ${ }^{d}$ Master student, department of psychology, University of Tehran, Iran

\section{H R O N I C L E}

\section{A B S T R A C T}

Article history:

Received April 23, 2012

Received in revised format

26 October 2012

Accepted 28 October 2012

Available online

October 292012

Keywords:

Workaholism

Nervous tendency

Self-sufficiency

Introversion-extroversion

Dominance-submission

Confidence and sociability
The purpose of this study is to examine the relationship between workaholism and personality traits among managers. A questionnaire consists of 141 items is developed with standard measures and 145 questionnaires are distributed among the managers and 113 ones are gathered where final response rate is $78 \%$ after removing two useless questionnaires. Cranach's alphas is reported greater than 0.70 , which shows the reliability of the subscales of the questionnaire. To test the hypotheses, different statistical techniques including one sample t test, analysis of variance (ANOVA), and correlation are implemented. Findings of the study show that demographical variables do not affect workaholism among managers in public organizations. In addition, among the personality variables, a significant relationship is detected between introversion and dominance with workaholism.

\section{Introduction}

The issue of workaholism in the past two decades has attracted many psychological and managerial researchers. Many studies have been performed on various aspects of this syndrome, its causes and effects and its consequences on work productivity (Peiperl, \& Jones, 2001; Porter, 1996) and especially on health (Lynley \& McMillan, 2004; Snir \& Harpaz, 2004; Taris et al., 2008). A workaholic person is driven to the work due to the existence of interest to work, or an existence of external request or due to an internal pressure, which puts the person under pressure with anxiety and guilt if a the workaholic person does not work (Burke, 2000; Burke et al., 2006; Fassel, 1990; Griffiths, 2011; Spence \& Robbins, 1992).

*Corresponding author.

E-mail addresses: eslami_ghasem@yahoo.com (G. Eslami) 


\subsection{Definition of workaholism}

The history of workaholic goes back to sixties when it was first used in an interview about workers who spent most of their time on working (Robinson et al., 2001; Schaufeli et al., 2008). Workaholism is also described as people whose needs for working is more than the common level and this could create serious problems for their health, welfare, personal relationships, and social performance (Lynley, \& McMillan, 2004).

Mosier (1983) proposed a simple definition for workaholics, which is "individuals who work more than 50 hours per week”. However, according to Machlowitz (1980) and Helldorfer (1987), what distinguish the workaholics from the others are their attitudes towards work not their working hours (Helldorfer, 1987). Peiperl \& Jones (2001) also believed that defining workaholism based on the working hours is wrong and could be misleading (Peiperl \& Jones, 2001).

Harpaz and Snir (2003) and Snir and Harpaz (2006) stated that the cognitive and behavioral aspects of workaholism are the important in defining this concept. According to Ng et al. (2007), Sorensen and Feldman's definition (2007), a workaholic is a person who enjoys doing his/her job and spends much of his/her free time on working.

Fassel (1990) describes four types of workaholics:

1. Obsessive workaholic who is always busy doing his/her job, and he/she is known more than others are.

2. Excessive workaholic who shows his/her usual working habit for various periods, but he/she comes to stages that he/she is out of the time, and he/she is hospitalized due to hard working.

3. Hidden workaholic who does some of his/her work at home or holidays.

4. Anorexic workaholic who evades doing his/her job by creating a stressful situation (Fassel, 1990).

Spence and Robins (1992) called a person as workaholic with the following characteristics,

$1-\mathrm{He} / \mathrm{she}$ is highly attracted to his/her job compared with others.

$2-\mathrm{He} / \mathrm{she}$ is driven to his/her job due to an internal pressure

3-He/she experiences the least amount of enjoyment while doing his job.

According to them, there is a difference between workaholism and willingness to do the work. A person who is willing to do his/her job is involved and highly attracted to his/her job like a workaholic, but he/she is not driven to his/her work. It means he/she can control him/herself for doing or not doing a job in every moment, and enjoys his/her job (Spence \& Robbins, 1992). Scott et al. (1997) suggests three different patterns for workaholism: compulsive-dependent, perfectionist, achievement-oriented. Obsessive workaholic person feels so much anxiety, and has a low job achievement due to low level of satisfaction from his/her life and job. Perfectionist workaholics have so much anxiety and experience mental and physical problems. They have excessive absenteeism and voluntary desertion and are not satisfied with their jobs. In addition, they have a low job achievement. Finally, achievement-oriented workaholics have a high level of job and life satisfaction, mental and physical health, job achievement and organizational citizenship behavior, and have a low level of anxiety and desertion (Lynley \& McMillan, 2004; Burke et al., 2006). Mudrack and Naughton (2001) defined workaholics as a combination of these characteristics: Workaholics involve themselves in useless and ineffective works, have a high tendency to interfere in others' works, and as this phenomenon gradually progresses in them, they try to take the responsibility of others' works (Mudrack \& Naughton, 2001). The primary objective of this study is to investigate the workaholism according to the Spence and Robins (1992) definition, among the Iranian managers of public organizations. On the contrary to public perception, there are managers with addictive behaviors to their work in Iranian public organizations. 


\subsection{Workahlosim causes and effects}

Some researchers specified in the past that organizational factors influence the emergence and continuation of workaholism (Harpaz \& Snir, 2003), factors like organizational culture (Helldorfer, 1987), and work conditions (Burke \& Matthiesen, 2004; Burke et al., 2004; Porter, 1996). In addition, some researchers examined the relationship between workaholism and depression, anger and anxiety (Haymon, 1992), perfectionism (Machlowitz, 1978; Spence \& Robbins, 1992), stress ( Jackson, 1992; Aziz \& Cunningham, 2008), contrast between family life and work life, and satisfaction with life and job (Bonebright et al., 2000; Taris et al., 2005; Piotrowski \& Vodanovich, 2006; Brady et al., 2008), self-disclosure and physical and mental health (Chamberlin \& Zhang, 2009; Lynley \& McMillan, 2004; Taris et al., 2008).

Personality is a good predictor of individuals' attitudes in the work environment, however; few studies have been accomplished to investigate the relationship between personality and workaholism (Liang \& Chu, 2009). Mudrack (2004) is the only researcher who did some research on the relationship between obsessive personality trait and workaholic (Mudrack, 2004). Ng et al. (2007) showed that there was a relationship between achievement-oriented personality trait and workaholism. They believed that workaholism can originate from three main resources including personality traits including confidence, achievement-oriented, personality type A, socio-cultural experiences including a stressful family life, competition, learning system and behavioral rein forcers including reward and punishment mechanisms in the organizations.

Gholipoor et al. (2008) showed that there was a statistically significant difference between personality traits and workaholism. Internal locus of control, self-belief, and narcissism had positive and significant relationship with workaholism and external locus of control had negative and significant relationship with workaholism. Since the personality plays an important role in individuals' perception, behavior, and reaction to the environment (Rabinz, 2007), it is expected that workaholism is associated with personality traits. Therefore, another objective of this study is to study the correlation between personality traits of the managers with various demographic information and their addictive behaviors to the work, to clarify which personality features influence the emergence of workaholism. Psychologists have different ideas about personality factors. Among them is Bern Reuter's theory (1933) in which he stated that personality has six factors including the neurotic tendency, self-sufficiency, introversion-extroversion, dominance-submission, confidence, and sociability. Individuals with various personality traits behave in a specific and different way. Based on the literature review and as the present study uses Bern Reuter's theory, an explanation of these factors and our research hypothesis in each personality trait are given in the following:

Neurotic tendency: These people are anxious, worried, fearful, lacking emotional stability, aggressive with regret and sadness, shy, and hopeless. They cannot make themselves ready for doing various works, and cannot do the jobs, completely. Individuals with a low level of this feature are relaxed and emotionally stable. These people usually encounter various situations without anxiety and sadness (Ganji, 2006). Therefore, the first research hypotheses is as follows,

$\mathrm{H}_{1}$ : Neurotic tendency has a negative relationship with workaholism.

Self-sufficiency and arrogance: All people are to some extent arrogant but a self-sufficient person has abnormally the characteristics of narcissism, confusion, fear, unrealistic and imaginary identity, emptiness feeling, insatiable desire for superiority, high sensitivity, anger, lack of ethical principles, illogical and inflexible, attributing their failures to others, ostentation. One of the places where arrogance and self-sufficiency could emerge is inside different organizations. These people can demonstrate their skills and capabilities as they are working, and consequently show up their abilities 
to others (Ganji, 2006). Following this, they spend significant amount of their time on working and this could lead to workaholism. Therefore, the second research hypotheses is stated as follows,

$\mathrm{H}_{2}$ : Self-sufficiency and arrogance lead to workaholism.

Introversion-Extroversion: extroverts are energized by the people from their external world and they pay more attention to other people and enjoy interactions with others. Introverts are energized by their internal world. They are satisfied with being with themselves and spending their time alone (Ganji, 2006). Therefore, the third research hypotheses is given as follows,

$\mathrm{H}_{3}$ : Introversion leads to workaholism and extroversion has a negative relationship with workaholism.

Dominance-submission: submitted people are afraid of rejection, they are obedient, maintain a low level of confidence, and are not aware of their individual rights or they cannot claim their rights. A dominant person is exactly the opposite of a submitted person. They need to reach power, influence other people and control them, become famous. The other features of dominant people are high confidence and gaining prestige. If these people are given important responsibilities, they will represent a powerful performance to show others their domination (Ganji, 2006). Therefore, the fourth research hypotheses is stated as follows,

$\mathrm{H}_{4}$ : Dominance leads to workaholism.

Confidence: One of the psychological factors, which have a substantial impact during the puberty, is confidence and self-belief. Self-belief plays an essential role in adjusting self-regulation and successful performing of the challenging jobs, and it is stated as the individual's belief source for controlling hard works (Ganji, 2006). Therefore, the fifth research hypothesis is as follows,

$\mathrm{H}_{5}$ : Confidence leads to workaholism.

Sociability: Human beings are sociable creatures, a creature with friendship with others is one of the necessities of his existential organization. Therefore, human makes friends with other people to reach happiness and grief, and to achieve good financial and mental results. This feature is seen in some people more than others (Ganji, 2006). Therefore the sixth research hypotheses is as follows,

$\mathrm{H}_{6}$ : Sociability has a negative relationship with workaholism.

Moreover, some studies have shown that workaholism is prevalent among men more than women are (Burke, \& Matthiesen, 2004; Harpaz \& Snir, 2003). However, this was not found in the study performed by Aziz and Cunningham (2008). Marital status and workaholism is also among the demographical variables, which have been investigated only by Snir and Harpaz (2004). The results showed that there is a statistically meaningful difference between singles and married individuals (Snir \& Harpaz, 2004). Therefore, the last of our research hypotheses is stated as follows,

$\mathrm{H}_{7}$ : There is a significant relationship between age, gender, educational level, and marital status with workaholism.

\section{Materials and Method}

This research is a descriptive correlation study, which examines the relationship between personality traits and workaholism among the managers of public organizations associated with seventeen agencies of Iranian ministries in Mashhad city. Based on the received list from Khorasan Razavi governor's office, there are 111 public organizations in this province where their main offices are located in city of Mashhad. They have 131330 official employed people including managers, employees, and servants. Among these, 2.5\% (3283 individuals) are the managers and higher 
authorities ${ }^{1}$, which are the participants of the present study. According to the formula for determining sample size with coefficient of error of 0.08 and confidence interval of 95\%, 144 people were selected by stratified random sampling method and then the questionnaires were distributed among them. 101 questionnaires were used for the final analysis.

\subsection{Validity and reliability of questionnaire}

The main material for gathering data was questionnaires. For this purpose, six personality traits questionnaire by Bern Router personality traits questionnaire and workaholism questionnaire by Spens and Robins (1992) were used. Bernreuter Personality Questionnaire has 125 questions in which the participants should answer the questions with "Yes", "No", or "I dont know". Based on these answers, individuals' personality is recognized. Many studies that have been done in organizational and commercial environments have confirmed the usefulness and effectiveness of this questionnaire (Ganji, 2006). Workaholism questionnaire has 16 questions on a 5-Lickert type scale. Both questionnaires have been validated (Gholipur et al., 2008). Cronbach's $\alpha$ was also used to check the reliability of the questionnaires. Cronbach's $\alpha$ were 0.71 and 0.79 for the workaholism and personality questionnaires, respectively, which shows a high reliability. To examine the research questions, inferential statistics were used. For this purpose, SPSS16 was used for correlation, one sample t test, and ANOVA.

\section{Results}

\subsection{Participants}

Descriptive statistics show that $87 \%$ of the participants are male and $13 \%$ are female. Thirty percent of the participants aged between 25 and 35, 33\% aged between 36 and 45, 32\% aged between 46 and 55 , and 5\% aged more than 56. From the educational point of view, Seven percent of the participants had a diploma, 9\% had an associate degree, 62\% had a bachelor degree, and $22 \%$ of them had a master or PhD degree. In addition, $12 \%$ of the respondents are single, and $88 \%$ are married.

\subsection{Testing hypotheses}

To assure the normality of the data, first Kolmogoroff - Smirnoff test was performed. Normality of the data was shown as the significant level of this test was higher than 0.05 . To examine the mean of workaholism, one-sample $t$ test was used. As the significant level of this test is less than 0.05 $(0.00<0.05)$, the null hypothesis which says that the mean workaholism equals with 3 (the cutoff point) is not supported. However, as both higher and lower intervals are positive, it can be concluded that workaholism is higher than the mean in error level of 0.05 (Table 1).

\section{Table1}

On sample test for workaholism

\begin{tabular}{ccccccc}
\hline & \multirow{2}{*}{$\mathrm{t}$} & \multicolumn{2}{c}{ sf } & \multicolumn{2}{c}{ Mean } & \multicolumn{2}{c}{$95 \%$ Confidence Interval of the } \\
& & & & Difference & Lower & Upper \\
\hline workaholism & 73.87 & 95 & 0.00 & 54.63 & 53.17 & 56.10 \\
\hline
\end{tabular}

To test whether gender and marital status affect workaholism, $t$ test was used. Based on the results in Table2, significant level is larger than $0.05(0.136>0.05)$ in Levene's test for equality of variances. Therefore, equal variances are assumed for this test. By assuming equal variances, the significant level is not less than $0.05(0.979>0.05)$. Therefore, workaholism is not affected by gender. In other words, there is no significant difference between males and females with regard to workaholism. By assuming equal variances regarding marital status, null hypothesis is supported based on the

${ }^{1}$ Statistical Yearbook of Mashhad in 2010 
significant level $(0.104>0.05)$. Therefore, workaholism is not affected by marital status. In other words, there is no significant difference between single and married individuals.

Table 2

The relationship between sex and marital status with workaholism

\begin{tabular}{|c|c|c|c|c|c|c|c|c|c|}
\hline \multirow{3}{*}{$\begin{array}{l}\text { The relationship } \\
\text { between sex and } \\
\text { workaholism }\end{array}$} & \multicolumn{3}{|c|}{$\begin{array}{l}\text { Levene's Test for Equality of } \\
\text { Variances }\end{array}$} & \multicolumn{6}{|c|}{ t-test for Equality of Means } \\
\hline & \multirow{2}{*}{$\mathrm{F}$} & \multirow{2}{*}{ Sig. } & \multirow{2}{*}{ variances } & \multirow{2}{*}{$\mathrm{t}$} & \multirow{2}{*}{$\mathrm{df}$} & \multirow{2}{*}{ Sig. (2-tailed) } & \multirow{2}{*}{$\begin{array}{c}\text { Mean } \\
\text { Difference }\end{array}$} & \multicolumn{2}{|c|}{$95 \%$ Confidence Interval } \\
\hline & & & & & & & & Lower & Upper \\
\hline workaholism & 2.26 & 0.136 & Equal & -0.27 & 92 & 0.979 & -0.6098 & -4.548 & 4.427 \\
\hline \multirow{3}{*}{$\begin{array}{l}\text { The relationship } \\
\text { between marital } \\
\text { status and } \\
\text { workaholism }\end{array}$} & \multicolumn{3}{|c|}{$\begin{array}{c}\text { Levene's Test for Equality of } \\
\text { Variances }\end{array}$} & \multicolumn{6}{|c|}{ t-test for Equality of Means } \\
\hline & \multirow{2}{*}{$\mathrm{F}$} & \multirow{2}{*}{ Sig. } & \multirow{2}{*}{ variances } & \multirow[b]{2}{*}{$\mathrm{t}$} & \multirow{2}{*}{ df } & \multirow{2}{*}{ Sig. (2-tailed) } & Mean & \multicolumn{2}{|c|}{ 95\% Confidence Interval } \\
\hline & & & & & & & Difference & Lower & Upper \\
\hline workaholism & 0.046 & 0.831 & Equal & -1.641 & 89 & 0.104 & -4.21 & -9.306 & 0.886 \\
\hline
\end{tabular}

To check whether workaholism is influenced by age and education, ANOVA (Analysis of Variance) was used. Based on Table 3, the significant level of this test with regard to education was larger than 0.05 (0.946). We can conclude that there is no difference between individuals with various educational levels (diploma, associate degree, bachelor, master, or $\mathrm{PhD}$ ) in 95\% confidence interval. This finding was also found with regard to age. In other words, based on the significant level of 0.676 , it can be said that the mean workaholism score was not significant among the managers with different ages.

Table 3

The effect education and age on the amount of workaholism

\begin{tabular}{|c|c|c|c|c|c|}
\hline Education & Sum of Squares & $\mathrm{df}$ & Mean Square & $\mathrm{F}$ & Sig. \\
\hline Between Groups & 20.363 & 3 & 6.788 & 0.124 & 0.946 \\
\hline Within Groups & 4890.28 & 89 & 54.947 & & \\
\hline Total & 4910.64 & 92 & & & \\
\hline age & Sum of Squares & $\mathrm{df}$ & Mean Square & $\mathrm{F}$ & Sig. \\
\hline Between Groups & 218.52 & 6 & 36.421 & 0.668 & 0.676 \\
\hline Within Groups & 4692.11 & 86 & 54.56 & & \\
\hline Total & 4910.64 & 92 & & & \\
\hline
\end{tabular}

To examine the relationships between Personality traits and workaholism, Cramer's V Correlation Coefficient was used. Based on the results in Table 4, there is no correlation between neurotic tendency and workaholism. This relationship is the same for self-sufficiency $(p=0.06)$ and confidence $(p=0.073)$. As the significant level is 0.004 for introversion and 0.005 for dominance, there is a significant correlation between these two features and workaholism.

\section{Table 4}

The relationship between Personality traits with workaholism

\begin{tabular}{lllllll}
\hline Personality traits & neurotic tendency & self-sufficiency & introversion & dominance & confidence & sociability \\
\hline Correlation Coefficient & 0.88 & 0.12 & 0.197 & 0.392 & 0.68 & -0.37 \\
\hline sig & 0.074 & 0.06 & 0.004 & 0.005 & 0.073 & 0.03 \\
\hline
\end{tabular}

The positive sign of Cramer's V Correlation Coefficient shows that this relationship is positive and direct, which means that people who have a higher level of these features are more workaholic. Regarding sociability, significant level $(p=0.03)$ showed that there is a significant relationship between this personality feature and workaholism, however, the negative sign indicates that it is a negative relationship. In other words, managers who are more sociable are less workaholic.

\section{Discussion and Conclusion}

Nowadays, executive managers are facing many challenges in their working environment. One of the biggest concerns of these managers is the existing imbalance between family life and work, which 
can easily influence their health and mental health. Workaholism is a common syndrome, which leads to life imbalance among the managers. This problem can happen for all the people (managers or employees) who work in public or private organizations. Studies done in the area of workaholism have shown different findings about this syndrome due to different participants. Findings of the present study have shown that there was no significant difference between workaholism in managers and employees with gender, marital status, age, and educational level. It is inconsistent with the findings of Aziz and Cunningham (2008) and is different with the findings of Snir and Harpaz (2004). It may be concluded that demographical variables do not impact workaholism of public organization managers. Among the personality variables, a substantial relationship was found between introversion, dominance with workaholism. It is inconsistent with the findings of Gholipur et al. (2008) and $\mathrm{Ng}$ et al. (2007).

There were some limitations in the present study. First, the only material used for assessing workaholism in this study was questionnaires. Second, there was no opportunity to interview with the managers because they were busy. Third, there were negative reactions and attitudes toward workaholism, and some managers didn't cooperate in filling the questionnaires.

In sum, it is suggested that this study is replicated in different organizations and cultures and the results are compared with the present study. Furthermore, the consequences of workaholim can be examined in individual aspects and organizational levels, and its relationship with variables like performance, job satisfaction, individual and organizational productivity, job burnout, and etc. could be in investigated.

\section{References}

Aziz, S. \& Cunningham, J. (2008). Workaholism, work stress, work-life imbalance: exploring gender's role. Gender in Management: An International Journal, 23(8), 553-566.

Bonebright, C. A., Clay, D. L., \& Ankenmann, R. D. (2000). The relationship of workaholism with work-life conflict, life satisfaction, and purpose in life. Journal of Counseling Psychology, 47, 469-476.

Brady, B. R., Vodanovich, S. J., \& Rotunda, R. (2008). The impact of workaholism on work-family conflict, job satisfaction, and perception of leisure activities. The Psychologist-Manager Journal, 11, 241-263.

Burke, R. J. (2000). Workaholism among Women managers: personal and workplace correlates. Journal of Managerial Psychology, 15(6), 520-534.

Burke, R. J. (2001). Workaholism in Organizations: the role of organizational values. Personal Review, 30(6), 637-645.

Burke, R. J., Harpaz, I., \& Snir, R. (2006). Workaholism in organizations: new research directions. Career Development International, 11(5), 369-373.

Burke, R.J., \& Koksal, H. (2002). Workaholism among a sample of Turkish managers and professionals: An exploratory study. Psychological Reports, 91, 60-68.

Burke, R. J., Koyuncu, M., \& Fiksenbaum L. (2008). Workaholism, work and extra-work satisfactions and well-being among professors in Turkey. Cross Cultural Management: An International Journal, 15(4), 353-366.

Burke, R. J., \& Matthiesen, S. (2004). Workaholism among Norwegian journalists: antecedents and consequences. Journal of the International Society for the Investigation of Stress, 20, 301-308.

Burke, R. J., Oberklaid, F., \& Burgess, Z. (2004). Workaholism among Australian women psychologists: antecedents and consequences. International Journal of Management, 21(3), 263-277.

Burke, R.J., Richardsen, A.M., \& Mortinussen, M. (2004). Workaholism among Norwegian managers: work and well-being outcomes. Journal of Organizational Change Management, 7, 459-470.

Chamberlin, M. C., \& Zhang, N. (2009). Workaholism, health, and self-acceptance. Journal of Counseling \& Development, 87, 159-169.

Ekhtiari, H. (2007). Challenge Ahead of Define Addiction. Addiction Journal, 2, 39-37(In Persian).

Fassel, D. (1990). Working ourselves to death: the high cost of workaholism and the rewards of recovery. New York, Harper Collins.

Ganji, H. (2006). Work Psychology. Tehran, Publisher: Savalan. (In Persian)

Gholipur, A., Nargesian, A. \& Tahmasbi, R. (2008). Workaholism: New challenge of human resource management. Management Knowledge, 81, 91-110 (In Persian). 
Griffiths, M.D. (2011), Workaholism: A 21st century addiction.The Psychologist: Bulletin of the British Psychological Society, 24(10),740-744.

Hamermesh, D. S., \& Slemrod, J. (2008). The economics of Workaholism: We should not have worked on this paper. B.E. Journal of Economic Analysis and Policy, 8(1), 17- 25.

Harpaz, I., \& Snir, R. (2003). Workaholism: Its definition and nature. Human Relations, 56, 291-319.

Haymon, S. W. (1992). The relationship of work addiction and depression, anxiety, and anger in college males. Unpublished Doctoral Dissertation, Florida State University.

Helldorfer, M. C. (1987). Church professionals and work addiction. Studies in Formative Spirituality, 8(2), 199-210.

Johnstone, A., \& Johnston, L. (2005). The relationship between organizational climate, occupational type and workaholism. New Zealand Journal of Psychology, 34, 181-188.

Liang, Y. W., \& Chu, C. M. (2009). Personality traits and personal and organizational inducements: antecedents of workaholism. Social Behavior and Personality, 37(5), 645-660.

Lynley, H.W., \& McMillan, M. (2004). Workaholism and health: implications for organizations. Journal of Organizational Change Management, 17(5), 509-519.

Jackson, D. L. (1992). Correlates of physical and emotional health among male and female workaholics. Unpublished Doctoral Dissertation, University of Oregon.

Machlowitz, M. M. (1978). Determining the effects of workaholism. Unpublished Doctoral Dissertation, Yale University.

Machlowitz, M. (1980). Workaholics, living with them, working with them. Reading, MA: Addison- Wesley.

Mudrack, P.E. (2004). Job involvement, obsessive-compulsive personality traits, and workaholic behavioral tendencies. Journal of Organizational Change Management, 17(5), 490-508.

Mudrack, P. E., \& Naughton, T. J. (2001). The assessment of workaholism as behavioral tendencies: scale development and preliminary empirical testing. International Journal of Stress Management, 8(2), 93-111.

Ng, T. W. H., Sorensen, K. L., \& Feldman, D. C. (2007). Dimensions, antecedents, and consequences of workaholism: a conceptual integration and extension. Journal of Organizational Behavior, 28(1), 111-136.

Peiperl, M., \& Jones, B. (2001). Workaholics and overworkers: Productivity or pathology? Group and Organization Management, 26, 369-393.

Piotrowski, C., \& Vodanovich, S. J. (2006). The interface between workaholism and work-family conflict: A review and conceptual framework. Organization Development Journal, 24(4), 84-92.

Porter, G. (1996). Organizational impact of workaholism: suggestions for researching the negative outcomes of excessive work. Journal of Occupational Health Psychology, 1, 70-84.

Porter, G. (2006). Profiles of workaholism among high-tech managers. Career Development International, 11(5), 440-462.

Robbins, S. P. (2007). Essentials of Organizational Behavior. 8th ed., Prentice Hall.

Robinson, B. E. (1999). The work addiction risk test: development of a tentative measure of workaholism. Perceptual and Motor Skills, 88, 199-210

Robinson, B. E., Carroll, J. J., \& Flowers, C. (2001). Marital estrangement, positive effect, and locus of control among spouses of workaholics and spouses of non workaholics: A national study. The American Journal of Family Therapy, 29(5), 397-410.

Schaufeli, W. B., Taris, T. W., \& Rhenen, W. (2008). Workaholism, burnout, and work engagement: three of a kind or three different kinds of employee well-being? Applied Psychology: An International Review, 57(2), 173-203.

Spence, J. T., \& Robbins, A. S. (1992). Workaholism: definition, measurement, and preliminary results. Journal of Personality Assessment, 58 (1), 160-178.

Snir. R., \& Harpaz. I. (2006). The workaholism phenomenon: a cross-national perspective. Career Development International, 11(5), 374-393.

Snir, R., \& Harpaz, I. (2004). Attitudinal and demographic antecedents of workaholism. Journal of Organizational Change Management, 17, 520-536.

Snir. R., \& Zohar, D. (2008). Workaholism as discretionary time investment at work: an experience-sampling study. Applied Psychology: An International Review, 57(1), 109-127.

Taris, T. W., Geurts, A. E., Schaufelib, W. B., Blonk, R. W. and Lagerveld, S. E. (2008). All day and all of the night: The relative contribution of two dimensions of workaholism to well-being in self-employed workers. Work \& Stress, 22(2), 153-165.

Taris, T. W., Schaufeli, W. B., \& Verhoeven, L. C. (2005). Workaholism in the Netherlands: Measurement and implications for job strain and work-non-work conflict. Applied Psychology: An International Review, 54, $37-60$. 